\title{
Seed quality and optimal spatial arrangement of fodder radish
}

\author{
Andréa dos Santos Oliveira ${ }^{1}$, Maria Laene Moreira de Carvalho ${ }^{2 *}$, Marcela Carlota Nery $^{2}$, João \\ Almir Oliveira², Renato Mendes Guimarães ${ }^{2}$ \\ ${ }^{1}$ UFLA - Programa de Pós-Graduação em Agronomia/Fitotecnia. \\ ${ }^{2}$ UFLA - Depto. de Agricultura, Setor de Sementes, CP. 3037 - 37200-000 - Lavras, MG - Brasil. \\ *Corresponding author <mlaenemc@dag.ufla.br> \\ Edited by: Edmilson José Ambrosano
}

\begin{abstract}
Besides the use of fodder radish (Raphanus sativus var. oleiferus Metzg.) as green manure plant cover crops and animal feed, the seeds have high oil content and low viscosity, ideal characteristics for the production of biodiesel. Studies related to the technology of seed production for this species are insufficient to define the best spatial arrangement of plants in the field that provides higher yields associated with high-quality seeds. Thus, we investigated the space and density between plants that would be ideal for the production of high quality fodder radish seeds. We evaluated the agronomic characteristics and physical, physiological and seed health quality in recently harvested fodder radish in row spacings of $0.2,0.4,0.6$, and $0.8 \mathrm{~m}$ and densities of $10,30,50$ and 70 seeds $\mathrm{m}^{-2}$. The quality and productivity of the fodder radish's seeds were affected by the spatial arrangement of plants in the field. Seeds harvested under the spacing of $0.2 \mathrm{~m}$ and density of 30 seeds $\mathrm{m}^{-2}$ had better performance and physical, physiological and health quality. Alternaria sp. incidence increased with greater spacing, while Fusarium sp. incidence decreased.
\end{abstract}

Key words: Raphanus sativus L. var. oleiferus Metzg, Brazil, production, sowing density

\section{Introduction}

Fodder radish (Raphanus sativus var. oleiferus Metzg.) has been used in the southern, southeastern and central western regions of Brazil in winter green manure (Lima et al., 2007), crop rotation and animal feeding (Crusciol et al., 2005) and its roots have physical effects on the soil that allow better aeration, preparation and soil decompaction (Muzilli, 2002). In addition to these uses, it has advantages in biodiesel production because of the low viscosity oil content of the grains, between $30 \%$ and $43 \%$ (Silva, 2006).

Technology and crop management for seed production differ in some aspects compared to grain and forage production (Moreira et al., 2004). For the fodder radish, green matter production techniques are known but the information available on seed and grain production and quality is divergent so technology for these characteristics is needed. Between the row spacing and the distance between plants in the row are the two factors that define the plant population. The correct choice of plant population is an extremely simple crop practice but has a great impact on yield (Severino et al., 2006), that is affected by the interaction between the plant, production environment and crop management. Among the management practices, the use of appropriate densities and spacing (Martins et al., 1999) can interfere especially in the quality of the seeds produced, as observed by Tourino et al. (2002) in cowpea cropping.

In fodder radish seed, information on the spatial arrangement has been reported for green matter production (Ohlandz et al., 2005; Crusciol et al., 2005 and Pereira, 2006). There is little information about cropping for seed production in the literature for the central western, South and part of Southeast Brazil (Calegari et al., 1993). There are hardly any recommendations for the southern region of Minas Gerais, so techniques need to be developed to obtain qual- ity seeds. Thus, the objective of the present study was to define the ideal spatial arrangement for fodder radish seed production in the winter in the southern region of Minas Gerais.

\section{Materials and Methods}

The field experiment was carried out from June to October 2007 in an experimental field in Lavras, state of Minas

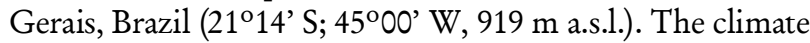
has a dry cold season from April to September and a warm and wet season from October to March, according to the Köppen classification. The soil is clayey Oxisol (Latossolo distrófico, fase cerrado, according to Brazilian classification).

Soil samples were collected from the experimental area and chemical analysis performed before sowing. Fertilization at sowing was carried out according to Ribeiro et al. (1999), using $300 \mathrm{~kg} \mathrm{ha}^{-1}$ of the NPK 08-28-16 formula. Lime was not applied. The chemical attributes of the soil at $0-0.2 \mathrm{~m}$ were: $\mathrm{pH}$ in water: 5.5 , organic matter: $21 \mathrm{~g} \mathrm{~kg}^{-1}$; available $\mathrm{P}$ : $18.4 \mathrm{mg} \mathrm{L}^{-1}$; available K: $75 \mathrm{mg} \mathrm{L}^{-1}$; available Ca: $25 \mathrm{mmol}$ $\mathrm{L}^{-1}$; available $\mathrm{Mg}: 6 \mathrm{mmol} \mathrm{c}_{\mathrm{c}}^{-1}$; available Al: $2 \mathrm{mmol} \mathrm{L}_{\mathrm{c}} \mathrm{L}^{-1}: 45^{\mathrm{c}}$ mmol $_{c} \mathrm{~L}^{-1}$ potential acidity, $33 \mathrm{mmol}_{\mathrm{c}} \mathrm{L}^{-1}$ sum of bases, cationic exchange capacity: $35 \mathrm{mmol}_{c} \mathrm{~L}^{-1}$ effective CTC, $78 \mathrm{mmol}$ $\mathrm{L}^{-1} \mathrm{CTC}$ pH 7.0 , base saturation: $42 \%$; available phosphorous resin: $19.9 \mathrm{mg} \mathrm{L}^{-1}$. After incorporating the fertilizer, the fodder radish CATI AL-1000 cultivar was sown by hand on June 12, 2007.

A randomized block design was used in a split plot factorial scheme with the sowing densities in the plot $(10,30$, 50 and 70 seeds $\left.\mathrm{m}^{-2}\right)$ and the spacing in the split plots $(0.2$; $0.4 ; 0.6$ and $0.8 \mathrm{~m}$ ). The number of seeds to be used in each subplot was calculated based on the seed germination $(80 \%)$, compensating for $100 \%$ plant emergence. Each field split plot consisted of six $5 \mathrm{~m}$ long rows and the four cen-

Sci. Agric. (Piracicaba, Braz.), v.68, n.4, p.417-423, July/August 2011 
tral rows were considered the useful area. Crop treatments were carried out, such as ant control, and the weeds were eliminated by hand hoeing.

The following data were recorded: final population, plant height, height of insertion of the first silique, number of siliques per plant, number of seeds per silique and yield. Scores for the lodging index followed a scale from 1 to 9 according to criteria established by Antunes and Silveira (1993) with score 1 for the erect plant and score 9 for all plants lodged.

The harvest was carried out by hand, the plants in the plot's useful area were pulled up and the seeds were dried to $7 \%$ moisture, with a variation of $\pm 0.5 \%$. The seeds were removed from the siliques by hand threshing, stamping and rubbing through sieves. Seeds were beneficiated in an air machine and sieves with $1.8 \mathrm{~mm} \mathrm{x} \mathrm{3/4} \mathrm{inch} \mathrm{mesh.} \mathrm{Assessments}$ were then carried out from December 2007 to February 2008. The seeds from each subplot were classified by size in 2.00 $\mathrm{mm}, 2.36 \mathrm{~mm}, 2.80 \mathrm{~mm}$ and $3.35 \mathrm{~mm}$ mesh sieves and the fractions calculated of each sieve in percentage. From this assessment, the seeds classified in the $2.36 \mathrm{~mm}$ mesh were used to assess the seed quality. A randomized complete design was used in the assessments carried out in the laboratory in a $4 \times 4$ factorial design with four sowing densities and four between row spacings.

The weight of 1,000 seeds was determined following methodology reported by Brazil (1992), where eight replications of 100 seeds were weighed on an analytical scale and the results expressed in grams. In the purity analysis, $30 \mathrm{~g}$ seeds were used from each plot, separated in pure seed fractions, other seeds and inert material according to Brasil (1992). The seed water content was determined by the oven method at $105 \pm 2{ }^{\circ} \mathrm{C}$, for $24 \mathrm{~h}$ (Brazil, 1992) using two $5 \mathrm{~g}$ seed replications. The water content was expressed in percentage of the wet base.

For the germination test, the seeds were sown in gerbox, sand substrate, at $20^{\circ} \mathrm{C}-30^{\circ} \mathrm{C}$ alternating temperatures, with an $8-16 \mathrm{~h}$ light period in a BOD chamber, subdivided in four 50 seed replications per treatment and the results expressed in percentage of normal seedlings on the fourth day (first count) and tenth day and the percentage of normal plants was calculated (Brazil, 1992). The germination speed index was calculated by computing daily the number of normal plants and calculated by the formula proposed by Maguire (1962).

For the emergence test in trays, the seeds were sown in plastic boxes with earth substrate: sand at the ratio of 1:2 and field capacity for $60 \%$ at $25^{\circ} \mathrm{C}$ in a plant growth chamber and $12 \mathrm{~h}$ light period. Four replications were used of 50 seeds per treatment and the results were expressed in percentage, on the $4^{\text {th }}$ day (initial stand) and $7^{\text {th }}$ day. The emergence speed index was calculated daily by the formula proposed by Maguire (1962). The plant canopy dry matter was obtained after drying in a forced air circulation chamber at $60^{\circ} \mathrm{C}$ for $24 \mathrm{~h}$. The electric conductivity test was carried out with four replications of 25 seeds per treatment, previously weighed and placed for imbibitions in beakers containing $75 \mathrm{~mL}$ de-ionized water at $25^{\circ} \mathrm{C}$ for $6 \mathrm{~h}$. After this period, the reading was carried out and the value obtained was divided by the weight of the seeds (Vieira and Krzyzanowski, 1999).

The blotter test was carried out on the seeds by the filter paper method or modified blotter test, with the use of 2.4-dichlorophenoxyacetic acid (2.4-D) and freezing, using 200 seeds, divided into four replications of 50 seeds placed in Petri dishes on three sheets of filter paper imbibed in distilled water, 2.4-D and agar (ISTA, 2008). Seven days after sowing the presence of fungi on the seeds was assessed using a stereoscopic microscope.

The analyses of variance for all the characteristics assessed were carried out using the SISVAR ${ }^{\circledR}$ statistical software. The data were submitted to analysis of variance and regression analysis and the means tested by the Scott Knott test at 5\%.

\section{Results and Discussion}

In the seed production period from June to October 2007 , the mean temperature in the region ranged from $17.1^{\circ} \mathrm{C}$ in July to $22.7^{\circ} \mathrm{C}$ in October and the relative air humidity from $51.2 \%$ in September to $66.8 \%$ in July (Figure 1). These data do not differ from average temperature and relative humidity observed in the last ten years (Figure 2), except for rainfall which was supplemented by irrigation. These climatic conditions are favorable for fodder radish seed production, because it is a species recommended for winter cropping in the southern, southeastern and central western regions of Brazil (Calegari et al., 1993). Flowering started early, 60 days after sowing. Nery (2008) $)^{1}$ produced fodder radish seeds in the same planting location and observed flowering only at 90 days after sowing. This reduction in the period to the start of flowering may have occurred because of the sowing period, carried out 30 days before the present research. Calegari et al. (1993) observed flowering in the winter crop sown in the southern region of Brazil ranging from 90 to 120 days. Light period sensitive plants reduce the plant cycle when sown late and respond positively to flowering in short days (Amabile et al., 2000). This reduction may be favorable to seed production as long as there are no reductions in yield and quality.

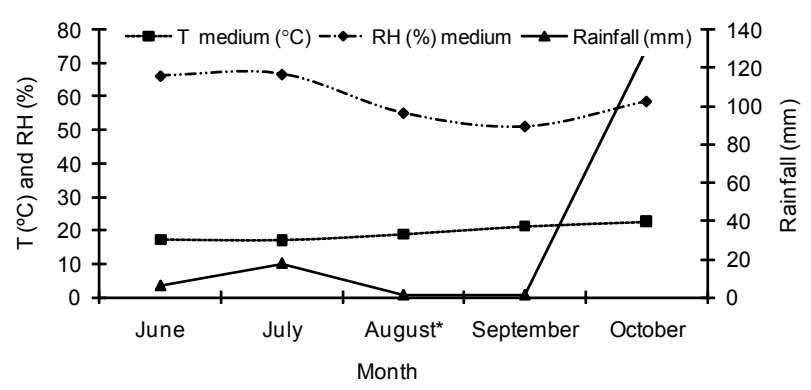

Figure 1 - Data for mean temperature $(\mathrm{T})$, relative air humidity $(\mathrm{RH})$ and mean rainfall during the field experiment. *Flowering start.

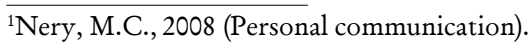




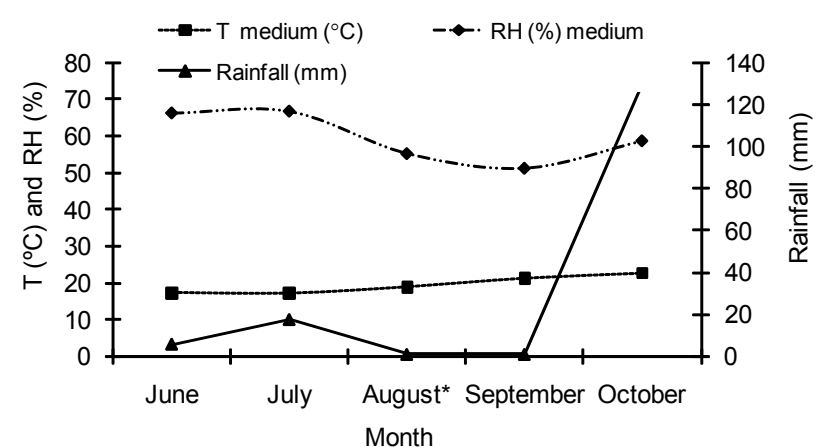

Figure 2 - Data for mean temperature $(\mathrm{T})$, relative air humidity $(\mathrm{RH})$ and mean rainfall during last ten years at the experimental area.

The analysis of variance showed effect of the sowing density $\times$ between row spacing interaction for plant height. The between row spacing affected the final plant population and yield. For the other characteristics analyzed, there was no significant effect of the spatial arrangement of the plants in the field.

The final plant population, assessed at 136 days after sowing, was influenced by the spacing. As the space between rows increased, the final plant population decreased linearly (Figure 3). However, although the sowing density ranged from 10 to 70 seeds $\mathrm{m}^{-2}$, the maximum population obtained was 42.5 plants $\mathrm{m}^{-2}$, and the minimum was 9.7 plants $\mathrm{m}^{-2}$, with a mean of 29 plants $\mathrm{m}^{-2}$.

The reduction in the final plant populations was accentuated in greater spacing, resulting in population close to the densities of 10 and 30 seeds $\mathrm{m}^{-2}$. In populations greater than 30 seeds $\mathrm{m}^{-2}$, reduction in the stand was observed of up to $81 \%$. Reductions in the final population between 10 and $25 \%$ are considered normal in plant populations, resulting from the use of low-quality seeds, problems at sowing, such as sowing depths or bird attack, pests and diseases that reduce the stand or even competition for water, light and nutrients (Arnon, 1975). Under this condition, the reduction in the final plant populations was probably due to competition between plants on the line and not because of the distance between the lines.

Responses in plant height varied greatly as the spacing and sowing density increased. This fact can be explained by the alteration in the establishment of the number of plants per area. Generally, when the population density increases and between row spacing decreases, there is a tendency for plant height to increase in function of the search for light, causing etiolating. Calegari et al. (1993) reported that fodder radish plant height can range from 1.0 to $1.8 \mathrm{~m}$, values observed in the present study (Figure 4).

Similarly to the plant hight, there was great variation in the height of insertion of the first silique (Table 1). Taller plants result in greater insertion heights of the first fruit, and this characteristic is also related to the population increase (Penariol et al., 2003). However, Argenta et al. (2001) reported that with the increase in plant density, there was a reduction in the plant height and fruit insertion height. There are alterations in the plant characteristics with the re-

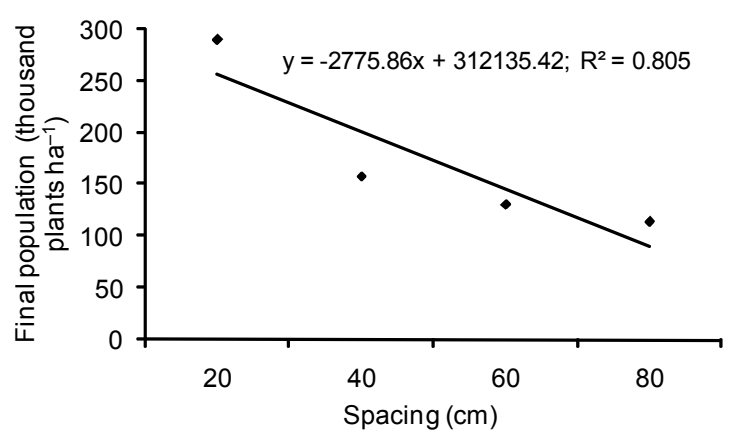

Figure 3 - Final fodder radish plant population as a function of spacing.

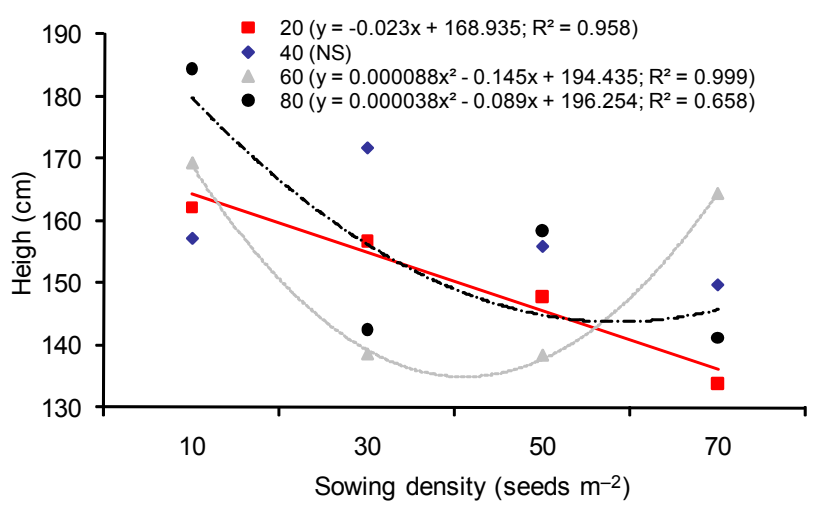

Figure 4 - Fodder radish plant height as a function of sowing densities and spacing.

Table 1 - Insertion height of the first silique in fodder radish plants produced under different spacing and population densities.

\begin{tabular}{|c|c|c|c|c|}
\hline \multirow{3}{*}{ Spacing } & \multicolumn{4}{|c|}{ Population densities } \\
\hline & 10 & 30 & 50 & 70 \\
\hline & \multicolumn{4}{|c|}{ seeds $\mathrm{m}^{-2}$} \\
\hline $\mathrm{m}$ & \multicolumn{4}{|c|}{ 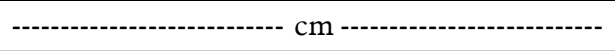 } \\
\hline 0.2 & $101.7 \mathrm{aA}$ & $91.7 \mathrm{bA}$ & $113.3 \mathrm{Aa}$ & $88.3 \mathrm{bA}$ \\
\hline 0.4 & $100.0 \mathrm{aA}$ & $125.0 \mathrm{aA}$ & $121.7 \mathrm{Aa}$ & $110.0 \mathrm{aA}$ \\
\hline 0.6 & $103.0 \mathrm{aA}$ & $102.7 \mathrm{bA}$ & $91.3 \mathrm{Ba}$ & $117.7 \mathrm{aA}$ \\
\hline 0.8 & $120.0 \mathrm{aA}$ & $77.7 \mathrm{bB}$ & $127.7 \mathrm{aA}$ & $88.3 \mathrm{bB}$ \\
\hline CV (\%) & \multicolumn{4}{|c|}{22} \\
\hline
\end{tabular}

Means followed by the same uppercase letter on the line and lowercase letter in the column do not differ (Scott-Knott test, $p<0.05)$.

duction in between row spacing, including stand height and lower height of insertion of the first fruit that increase competition among the plants in the same row for the reduced solar radiation in the crop canopy (Argenta et al., 2001). The maximum height of insertion of the siliqua is a desirable feature in the mechanical harvesting of seeds by allowing the highest setting of the harvester, but may increase the percentage of non-harvested pods. 
Higher rates of plant lodging were observed in the higher sowing densities and smaller spacing (Table 2) with scores of 7, 5 and 3 . These scores were 2 and 1 in lower population densities and greater between the row spacing, regardless of the sowing density used. The lower lodging rates observed in the larger spaces between rows and sowing densities may be related to the reduction in the final plant population of up to $81 \%$, because of the reduction in competition among plants and etiolating. Calegari et al. (1993) recommended $0.4 \mathrm{~m}$ between the row spacing for seed production, because between a row spacing less than this and a high population density can cause lodging problems. At greater densities the plants tend to lodge more (Tourino et al., 2002; Moreira et al., 2004) that can be a negative effect when using mechanized harvesting, reducing its efficiency, yield and even the seed quality.

The number of siliques per plant ranged from 90 to 223 , and no increase was observed in the number of siliques per plant related to the increase in density or spacing. Variations were not observed in the number of seeds per silique with the increase in spacing or density $(5$ and 8 seeds per silique). The absence of variation in the number of seeds per silique in function of spacing or sowing density was also observed by Santos et al. (2002) for the same species when cropped under no till, with $25 \mathrm{~cm}$ between row spacing.

Spacing affected fodder radish seed yield, that tended to decrease as the between row spacing increased (Figure 5). The highest yields were obtained in the smallest between row spacing, with 1,327 and $662.67 \mathrm{~kg} \mathrm{ha}^{-1}$, values higher than the mean obtained in studies on fodder radish, in which mean yields were observed of $428 \mathrm{~kg} \mathrm{ha}^{-1}$ (Silva et al., 2006) and $123.7 \mathrm{~kg} \mathrm{ha}^{-1}$ (Sá, 2005). Hernani et al. (1995) stated that mean grain yields can be obtained of $1,200 \mathrm{~kg} \mathrm{ha}^{-1}$ in between row spacing of up to $0.40 \mathrm{~m}$. Calegari et al. (1993) reported fodder radish yield of around 300 to $450 \mathrm{~kg} \mathrm{ha}^{-1}$.

In the seed quality assessment, sowing density only affected the emergence speed index, initial stand, electric conductivity and health. Significant effects were not observed in the weight of 1,000 seeds, first count, germination, emergence and plant dry matter. The seed water content obtained was $7 \%$, and this was the typical hygroscopic balance for oil seed species (Burrell et al., 1980). The mean

Table 2 - Scores for the lodging index in function of different spacing and population densities.

\begin{tabular}{llll}
\hline \multirow{3}{*}{ Spacing } & \multicolumn{3}{c}{ Population densities } \\
\cline { 2 - 4 } & $10 \quad 30 \quad 50$ & 70 \\
\cline { 2 - 4 } & \multicolumn{3}{c}{ seeds $\mathrm{m}^{-2}$} \\
\hline
\end{tabular}

\begin{tabular}{lllll}
\hline $\mathrm{m}$ & & & & \\
0.2 & 1 & 3 & 5 & 7 \\
0.4 & 1 & 2 & 3 & 7 \\
0.6 & 1 & 2 & 2 & 2 \\
0.8 & 1 & 1 & 2 & 2 \\
\hline
\end{tabular}

purity percentage ranged from $89.3 \%$ to $97.9 \%$. The variation in the weight of 1000 seeds was from $9.57 \mathrm{~g}$ to $10.54 \mathrm{~g}$.

The fodder radish seed germination was above $84 \%$ which was higher than the standard established for commercialization of the seeds of this species, whose minimum value is $60 \%$. Emergence was $79 \%$. The results did not vary among the treatments for the first count, germination speed index and plant dry matter (Table 3). For the emergence speed index, initial stand and electrical conductivity, the effect of sowing density was observed on the seed quality. A tendency was observed (Figures 6 and 7) to a greater emergence speed and initial stand in the seeds produced under sowing densities of 30 and 50 seeds $\mathrm{m}^{-2}$. Densities greater than 50 seeds $\mathrm{m}^{-2}$ or less than 30 seeds $\mathrm{m}^{-2}$ did not reduce the seed vigor.

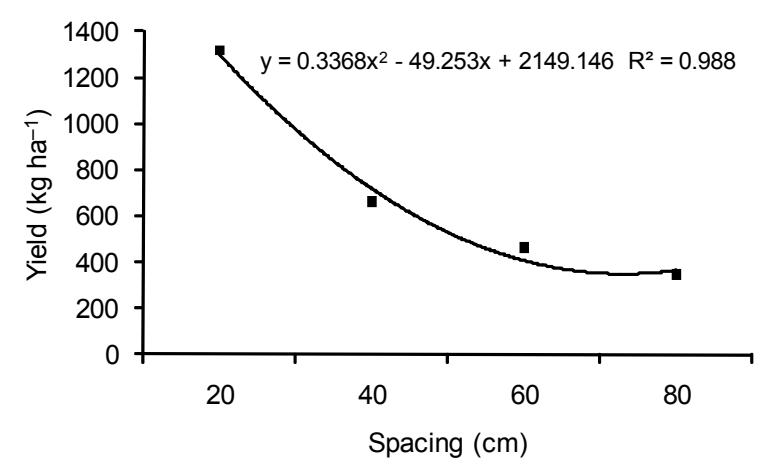

Figure 5 - Fodder radish seed yield as a function of row spacing.

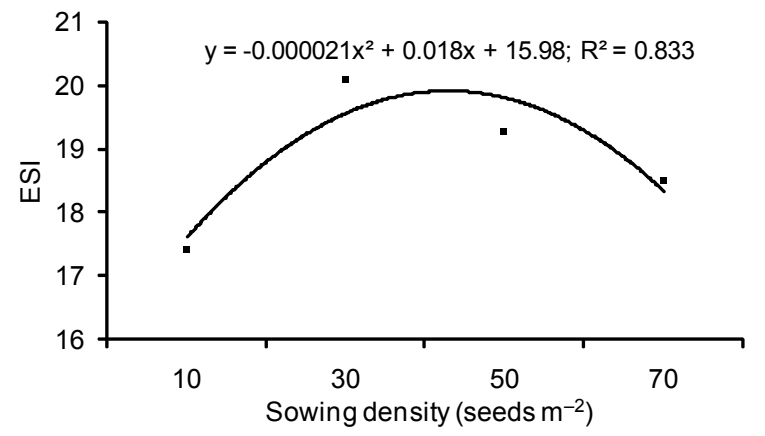

Figure 6-Emergence speed index of fodder radish seedlings as a function of sowing densities.

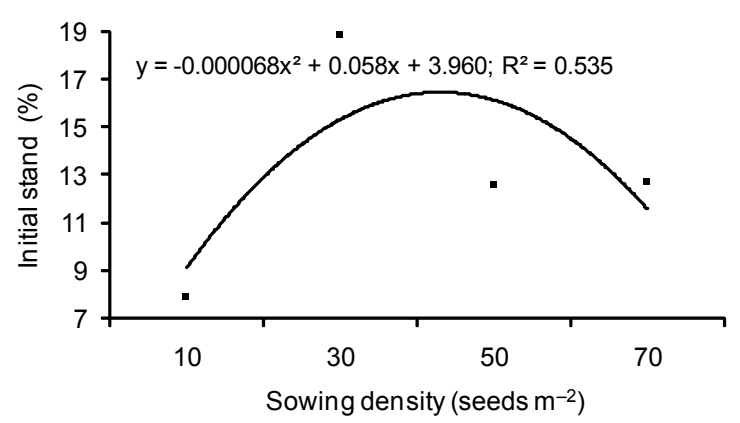

Figure 7 - Initial stand of fodder radish seedlings as a function of sowing densities. 
Table 3 - First count, germination, germination speed index, emergence and plant dry matter in fodder radish seeds produced under different spacing and sowing densities.

\begin{tabular}{|c|c|c|c|c|}
\hline \multirow{3}{*}{ Spacing } & \multicolumn{4}{|c|}{ Population densities } \\
\hline & 10 & 30 & 50 & 70 \\
\hline & \multicolumn{4}{|c|}{ seeds $\mathrm{m}^{-2}$} \\
\hline & \multicolumn{4}{|c|}{ First count } \\
\hline $\mathrm{m}$ & \multicolumn{4}{|c|}{ 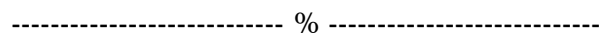 } \\
\hline 0.2 & 14 & 10 & 13 & 11 \\
\hline 0.4 & 23 & 18 & 14 & 7 \\
\hline 0.6 & 11 & 18 & 12 & 14 \\
\hline 0.8 & 11 & 16 & 9 & 12 \\
\hline \multirow[t]{2}{*}{$\mathrm{CV}(\%)$} & \multicolumn{4}{|c|}{31} \\
\hline & \multicolumn{4}{|c|}{ Germination } \\
\hline $\mathrm{m}$ & \multicolumn{4}{|c|}{ 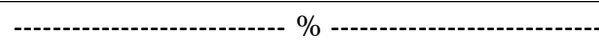 } \\
\hline 0.2 & 89 & 89 & 84 & 91 \\
\hline 0.4 & 93 & 86 & 91 & 88 \\
\hline 0.6 & 87 & 91 & 90 & 91 \\
\hline 0.8 & 91 & 89 & 88 & 91 \\
\hline \multirow[t]{2}{*}{ CV(\%) } & \multicolumn{4}{|c|}{9} \\
\hline & \multicolumn{4}{|c|}{ Germination speed index } \\
\hline
\end{tabular}

\begin{tabular}{lrrrr} 
& & & & \\
\cline { 2 - 5 } $\mathrm{m}$ & & & & \\
0.2 & 11.0 & 10.7 & 9.7 & 10.3 \\
0.4 & 11.7 & 10.0 & 10.7 & 10.3 \\
0.6 & 10.3 & 11.0 & 10.3 & 10.0 \\
0.8 & 10.3 & 10.7 & 10.7 & 10.7 \\
\hline $\mathrm{CV}(\%)$ & \multicolumn{5}{c}{9} \\
\hline
\end{tabular}

\begin{tabular}{|c|c|c|c|c|}
\hline \multirow[b]{2}{*}{$\mathrm{m}$} & \multicolumn{4}{|c|}{ Emergence } \\
\hline & \multicolumn{4}{|c|}{ 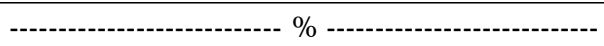 } \\
\hline 0.2 & 79 & 88 & 80 & 86 \\
\hline 0.4 & 85 & 89 & 85 & 86 \\
\hline 0.6 & 82 & 86 & 87 & 83 \\
\hline 0.8 & 81 & 86 & 85 & 84 \\
\hline \multirow[t]{2}{*}{$\mathrm{CV}(\%)$} & \multicolumn{4}{|c|}{10} \\
\hline & \multicolumn{4}{|c|}{ Seedling dry matter } \\
\hline $\mathrm{m}$ & \multicolumn{4}{|c|}{--------------- mg per seedling ---------------- } \\
\hline 0.2 & 8.22 & 7.46 & 7.82 & 7.73 \\
\hline 0.4 & 7.03 & 8.15 & 8.98 & 8.46 \\
\hline 0.6 & 7.98 & 7.32 & 9.67 & 8.25 \\
\hline 0.8 & 6.94 & 8.56 & 10.15 & 8.22 \\
\hline $\mathrm{CV}(\%)$ & \multicolumn{4}{|c|}{9} \\
\hline
\end{tabular}

In the electrical conductivity test, there was a tendency to a reduction at the 30 seeds $\mathrm{m}^{-2}$ density and to increase at densities of 50 and 70 seeds $\mathrm{m}^{-2}$ (Figure 8). These tests showed differences in seed quality when submitted to different sowing densities, indicating that better quality fodder radish seeds can be produced at sowing densities close to 30 seeds $\mathrm{m}^{-2}$.
The association of the Alternaria sp., Cladosporium sp., Aspergillus sp., Penicillium sp., Fusarium sp. and Phoma sp. was observed in the seeds and the fungi and the greatest incidence here reported were for the Alternaria sp., Fusarium sp. and Cladosporium sp. (Figure 9A and B). There was an effect of sowing density on the incidence of the Alternaria sp. and Fusarium sp. fungi. A linear tendency to increase for Alternaria sp. was observed. As the density increased (Figure $9 \mathrm{~A}$ ) there was a linear tendency to decrease in the Fusarium sp. incidence when the sowing density was increased (Figure 9B).

The Alternaria sp. incidence tended to increase linearly with increasing sowing density. This microorganism is associated with fodder radish seeds and takes effect in dampingoff. Crochemore and Piza (1994) worked with fodder radish seeds and observed the incidence of fungi of the Alternaria sp. genus such as Alternaria raphani, Alternaria tenuis and Alternaria brassicae associated to the fodder radish seeds. Cladosporium sp. incidence in the fodder radish seeds varied in the different population arrangements, as shown in Table 4. The highest incidence was observed in the 10 seeds $\mathrm{m}^{-2}$ sowing density and $20 \mathrm{~cm}$ between row spacing $(40 \%)$.

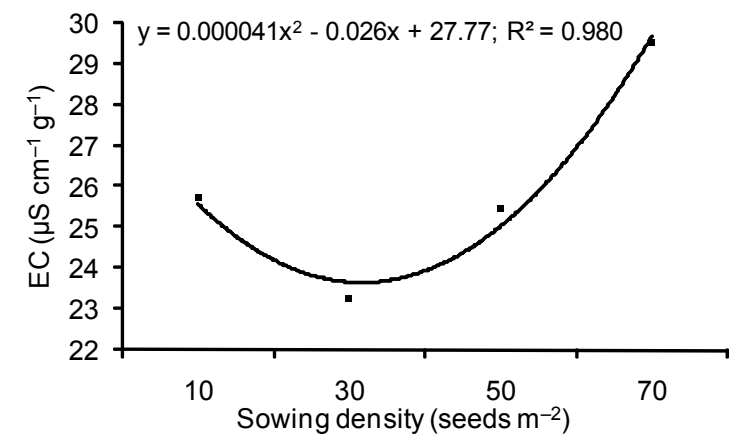

Figure 8 - Electrical conductivity (EC) of fodder radish seeds as a function of sowing densities.

Table 4 - Cladosporium sp. incidence in fodder radish seeds produced under different spacing and population densities.

\begin{tabular}{lrrrr}
\hline & \multicolumn{5}{c}{ Sowing densities } \\
\cline { 2 - 5 } Spacing & 10 & \multicolumn{4}{c}{50} & 70 \\
\cline { 2 - 5 } & \multicolumn{5}{c}{ Cladosporium sp. } \\
\cline { 2 - 5 } & \multicolumn{5}{c}{ seeds m ${ }^{-2}$} \\
\hline $\mathrm{m}$ & $40 \mathrm{aA}$ & $7 \mathrm{aA}$ & $12 \mathrm{aA}$ & $19 \mathrm{aA}$ \\
0.2 & $9 \mathrm{bA}$ & $1 \mathrm{aA}$ & $5 \mathrm{aA}$ & $12 \mathrm{aA}$ \\
0.4 & $11 \mathrm{bA}$ & $3 \mathrm{aA}$ & $16 \mathrm{aA}$ & $23 \mathrm{aA}$ \\
0.6 & $10 \mathrm{bA}$ & $14 \mathrm{aA}$ & $4 \mathrm{aA}$ \\
0.8 & \multicolumn{5}{c}{$12 \mathrm{Aa}$} \\
\hline CV (\%) & \multicolumn{5}{c}{58} \\
\hline
\end{tabular}

Means followed by the same uppercase letter on the line and lowercase letter in the column do not differ (Scott-Knott and F tests, $p>0.05$ ). 

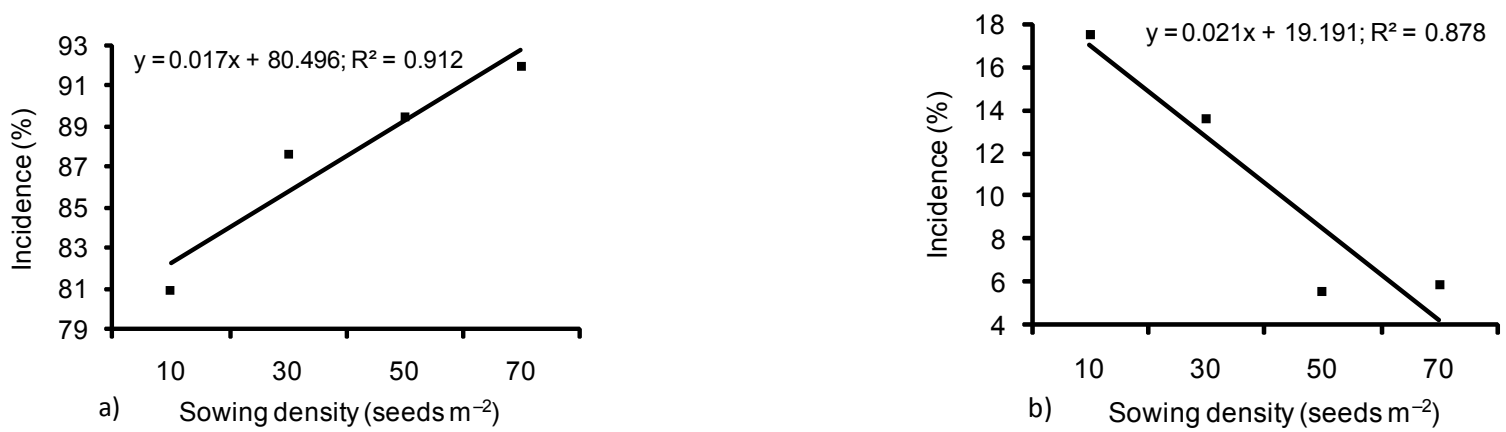

Figure 9 - Incidence of Alternaria sp. (A) and Fusarium sp. (B) fungi in fodder radish seeds as a function of sowing density.

\section{Conclusions}

Fodder radish seed quality and yield were affected by the spatial arrangement of the plants in the field. Row spacing or densities, respectively, greater than $0.20 \mathrm{~m}$ or than 30 seeds $\mathrm{m}^{-2}$, negatively affected all the following characteristics: final plant stand, yield as well as seed physiological and health quality. Alternaria sp. incidence was increased with high spacing, while the incidence of Fusarium sp. was reduced.

\section{Acknowledgements}

To CAPES, CNPq and FAPEMIG for financial support, and grants for master research.

\section{References}

Amabile, R.F.; Fancelli, A.L.; Carvalho, A.M. 2000. Evaluation of green manures in different sowing dates and row-spacings in the cerrados region. Pesquisa Agropecuária Brasileira 35: 47-54. (in Portuguese, with abstract in English).

Antunes, I.F.; Silveira, E.P. 1993. Bean: Field Manual. Embrapa-CPACT, Pelotas, RS, Brasil. (in Portuguese).

Argenta, G.S.; Silva, P.R. F.; Bortolini, C.G.; Forsthofer, E.L.; Manjabosco, E.A.; Neto, V.B. 2001. Response of maize single-cross hybrids to reduced row spacing. Pesquisa Agropecuária Brasileira 36: 71-78. (in Portuguese, with abstract in English).

Arnon, I. 1975. Plant population density. p. 76-78. In: Arnon, I., ed. Mineral nutrition of maize. International Potash Institute, Bern, Switzerland.

Brazil. Ministry of Agriculture and Agrarian Reform. 1992b. Rules for Seed Testing. SNDA/DNDV/CLAV, Brasília, DF, Brazil. 365 p. (in Portuguese).

Burrell, N.J.; Knight, G.P.; Armitage, D.M.; Hill, S.T. 1980. Determination of the time available for drying rapeseed before the appearance of surface moulds. Journal of Stored Products Research. Oxford, 16: $115-118$

Calegari, A.; Alcântara, P.B.; Miyasaka, S.; Amado, T. J. C. 1993. Characterization of the main species of green manure: fodder radish. part III. p. 302-304. In.: Calegari, A.; Mondardo, A.; Bulisani, E.A.; Wildner, L.P.; Costa, M.B.B.; Alcântara, P.B.; Miyasaka, S.; Amado, T.J.C. Green manure in southern Brazil. AS-PTA, Rio de Janeiro, RJ, Brazil. (in Portuguese).

Crochemore, M.L.; Piza, S.M.T. 1994. Germination and sanity of turnip seeds stored in different types of package. Pesquisa Agropecuária Brasileira 29: 677-680. (in Portuguese, with abstract in English).
Crusciol, C.A.C.; Cottica, R.L.; Lima, E.V.; Andreotti, M.; Moro, E.; Marconi, E. 2005. Persistence and nutrients release of forage turnip straw utilized as mulching in no-tillage crop system. Pesquisa Agropecuária Brasileira 40: 161-168. (in Portuguese, with abstract in English).

Hernani, L.C.; Endres, V.C.; Pitol, C.; Salton, J.C. 1995. Green Manures Fall/Winter in Mato Grosso do Sul. Embrapa-CPAO, Dourados, MS, Brazil. 93 p. (in Portuguese).

International Seed Testing Association [ISTA]. 2008. Seed health testing. In: International rules for seed testing. Bassersdorf, Switzerland.

Lima, J.D.; Aldrighi, M.; Sakai, R.K.; Soliman, E.P.; Moraes, W.S. 2007. Performance of turnip (Raphanus sativus L.) and wild radish (Raphanus raphanistrum L.) as green manure. Pesquisa Agropecuaria Tropical 37: 60-63. (in Portuguese, with abstract in English).

Maguire, J.D. 1962. Speed of germination: aid in selection and evaluation for seedling emergence and vigor. Crop Science 2: 176-177.

Martins, M.C.; Câmara, G.M.S.; Peixoto, C.P.; Marchiori, L.F.S.; Leonardo, V.; Mattiazzi, P. 1999. Sowing date, planting density and vegetative performance of soybean cultivars. Scientia Agricola 56: 851-858. (in Portuguese, with abstract in English).

Moreira, L.B.; Lopes, H.M.; Nascimento, S.G.M. 2004. Effects of plant population on agronomic characteristics, yield and quality seeds of pearl millet (Pennisetum glaucum (L.) R. Brown), cv. ENA 1. Agronomia 38: 78-82. (in Portuguese, with abstract in English).

Muzilli, O. 2002. Management of organic matter in no-tillage system: the experience in the State of Parana. Informações Agronômicas 100: 6-10. (in Portuguese).

Ohlandz, R.A.A.; Sousa, L.C.F.; Hernani, L.C.; Marchettis, M.E.; Gonçalves, M.C. 2005. Soil cover crops and nitrogen fertilizing in corn in no tillage planting. Ciência e Agrotecnologia 29: 538544 (in Portuguese, with abstract in English).

Penariol, F.G.; Fornasieri Filho, D.; Coicev, L.; Bordin, L.; Farinelli, R.; 2003. Performance of maize cultivars sown in different row widths and population densities in off-season cultivation. Revista Brasileira de Milho e Sorgo 2: 52-60. (in Portuguese, with abstract in English).

Pereira, A.R. 2006. How to Select Plants For Degraded Areas And Erosion Control. FAPI, Belo Horizonte, MG, Brazil. (in Portuguese).

Ribeiro, A.C.; Guimarães, P.T.G.; Vicente, V.H.A. 1999. Lime and Fertilizer Use Recommendations in the Minas Gerais: $5^{\text {a }}$ Approximation. CFSEMG, Lavras, MG, Brazil. (in Portuguese).

Sá, R.O. Genetic Variability Among Fodder Radish Half-Sib Progenies, CATI AL 1000 Cultivar. 2005. Faculty of Agricultural Sciences, State-University of São Paulo, SP, Brazil. 49 p. (in Portuguese). 
Santos, H.P., Fontaneli, R.S., Baier, A.C., Tomm, G.O. 2002. Main forage on no tillage Crop-Pasture Rotation in Plateau and Missions Regions in the Rio Grande do Sul. Embrapa Trigo, Passo Fundo, RS, Brazil. (in Portuguese).

Severino, L.S.; Moraes, C.R.A.; Gondim, T.M.S.; Cardoso, G.D.; Beltrão, N.E.M. 2006. Yield of castor planted at different row space. Revista Ciência Agronômica 37: 50-54 (in Portuguese, with abstract in English).

Silva, A.R.B.; Silva, T.R.B.; Silva, M.L.L.; Vianna, J.F.; Martinez, M.M.; Vianas, L.H.; Silva, R.F. 2006. Behavior of fodder radish (Raphanus sativus L.) cultivars depending on the variations of row spacing. Available in: http://www.biodiesel.gov.br/docs/congressso2006/ agricultura/ComportamentoCultivaresNabo.pdf. [Accessed Jan. 15, 2007].
Tourino, M.C.C.; Rezende, P.M.; Salvador, N. 2002. Row spacing, plant density and intrarow plant spacing uniformity effect on soybean yield and agronomic characteristics. Pesquisa Agropecuária Brasileira 37: 1071-1077. (in Portuguese, with abstract in English).

Vieira, R.D.; Krzyzanowski, F. 1999. Electrical condutivity test. chap. 4, p. 1-26. In: Krzyzanowski, F.; Vieira, R.D.; Franca Neto, J.B., eds. Seed vigor: concepts and tests. ABRATES, Londrina, PR, Brazil. (in Portuguese).

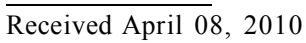

Accepted November 22, 2010 